\title{
Visishtādvaita and Wahdatul-Wujūd: Points of comparison and departure
}

\author{
Zaheer Ali Khan Sharvani* and S. Abdul Sattar**
}

\section{Abstract}

Not only in philosophy but in religion as well, concepts such as God, World and Man are discussed quite considerably. Nevertheless, an understanding of these concepts requires careful, detailed and systematic analyses. One of the methods of achieving the same is to use a comparative framework. Within Islam, WahdatulWujud (Unity of Existence) is an important mystical and philosophical perspective that has witnessed a tumultuous journey. It has however played a dominant role in Islamic thought. Within Indian philosophy, Vedānta has played a very influential role. Visistādvaita as a school of thought has also played a great role to interpret core philosophical concepts of Upanishads, Bhagavad Gita and Brahma Sutras. In this research paper, we attempt to provide a comparative analysis of Visistädvaita and Wahdatul-Wujud marking out the aspects of similarity and departures. What stands out as relevant and insightful as an implication of the comparative method is an understanding of these two approaches. Wahdatul-Wujud is redefined as a panentheistic

\footnotetext{
* Research Scholar, Department of Philosophy, and Prof. S. Abdul Sattar, Head, Department of Philosophy, Sri Venkateswara University, Tirupati, India; zaheer.info@gmail.com

** Head, Department of Philosophy, Sri Venkateswara University, Tirupati; sabdulsattarsvu@gmail.com
} 
philosophy which believes that God exists inside of everything, but is at the same time, transcendent of everything. In this type ofbelief, God is seen as an eternal spark of all things, the Prime Mover. Quite similarly, Visistādvaita, on the other hand is conceived as a Qualified Non- dualistic philosophy which believes in subsuming every diverse phenomena and experience under an underlying unity.

Keywords: Visistādvaita, Brahman, Atman, Wahdatul-Wujud, Islam, Tawhid, Shirk

\section{Introduction:}

In philosophy of religion, some philosophical schools show similarities with other religions. Though they look apparently different, they also intrigue the students of philosophy into comparing and studying the contrast that exists between them. When such comparisons are done, many similarities and differences can be identified which gives us a clearer understanding of the schools. Many philosophical schools like Advaita and Wahdatul-Wujūd, Dvaita and Wahdat-ash-Shuhüd, etc. could be compared with each other for an enhanced understanding of the tenets of each of the schools. The objective of this research paper is to compare and assimilate the key concepts in the two philosophies - Visishtādvaita and Wahdatul-Wujūd. Before the comparison is done, it is imperative for us to note the four integral concepts that would be significant for the analyses conducted in this research paper - Visishtādvaita, Wahdalul-Wujūd, Tawhid and Sirk.

Visishtādvaita (also can be written as Visishtādvaita or Vishishtadvaita), "Qualified Non-dualism" or "Non-dualism of the Qualified" in Sanskrit, was propounded by Ramanuja (1017 -1137 CE) who argued that the jivantman (individual soul) is a part of Brahman, and hence is similar to it, but not identical. The main difference from Advaita is that in Visishtädvaita, Brahman is asserted to have attributes, including individual, conscious souls and matter. Brahman, matter, and the individual souls are distinct but mutually inseparable entities. This school propounds Bhakti or 
devotion to God visualized as Vishnu, to be the path to liberation. Māya is seen as the creative power of God.

Wahdatul-Wujūd (also can be written as Wahadat al-Wujood), "Unity of Being" in Arabic, is a Sufi philosophy that emphasizes on the fact that there are no true existences except the Ultimate Truth (God). In other words, the only truth within the universe is God and that all things exist within God only.

Tawhid, "doctrine of Oneness of God" in Arabic, is the concept of monotheism in Islam. It is the religion's most fundamental concept and holds that God (Allāh) is One (Wāhid) and Unique (Aḥad). Strictly, the word connotes "unification," "union" or "combination" 1 .

Shirk, "to share" in Arabic, is also a concept from Islamic philosophy. The word means the establishment of "partners" placed beside God. It is the antithesis of Tawhid'. It also means supplicating to others than God, or believing that they hold the same attributes as Him in an equal or lesser degree. Within Islam, Shirk is an unforgivable sin if it remained unpardoned before death: God may forgive any sin if one dies in that state except for committing Shirk ${ }^{3}$.

\section{Visishtādvaita:}

VisishtädvaitaVedānta is one version of Vedānta. Vedānta is nominally a school of Indian philosophy, although in reality it is a label for any form of hermeneutics that attempts to provide a consistent interpretation of the philosophy of the Upanisads or, more formally, the canonical summary of the Upanisads, Bhagavad Gita and BrahmaSūtra.

Visishtädvaitais is often translated as "Qualified Non-dualism" or "Non-dualism of the Qualified." This school grew out of the Vaishnava (worship of the god Vishnu) movement prominent in South India from the 7th century CE. One of the early Brahmans (members of the priestly class) who began to guide the movement was Nathamuni (10th century), head priest of the temple at Srirangam (in modern Tamil Nadu state). He was succeeded by 
Yamuna (11th century), who wrote philosophical treatises but no commentaries. Yamuna's successor, Ramanuja wrote commentaries on the BrahmaSutras (the Shribhashya, "Beautiful Commentary") and on the Bhagavad Gita and a treatise on the Upanișads, the Vedarthasamgraha ("Summary of the Meaning of the Veda").

Ramanuja was the first of the Vedanta thinkers to make the cornerstone of his system, the identification of a personal God with the Brahman, or Absolute Reality, of the Upanișads and the Vedanta Sutras. As a personal God, Brahman possesses all the good qualities in a perfect degree, and Ramanuja does not tire of mentioning them. For him the relation between the infinite and the finite is similar to the one between the soul and the body. Hence, nonduality is maintained, while differences can still be stated. Soul and matter are totally dependent on God for their existence, as is the body on the soul.

Visishtädvaita is closely related to Sri Vaishnava, hence it is seen more as a philosophy of religion rather than an independent spiritual philosophy that is followed by any religion.

Visishtādvaita as the term indicates is Advaita that accepts Viseshās. Visishtadvaitins accept basic Advaita or non-duality of Jiva and Para. In the liberated state Jiva is Para. Jiva has Viseshas of consciousness in unliberated state, unlike in Advaita where Jiva is just a witness even in unliberated state. In fact, liberation is not for the Jivatma, it is for the entity Jiva consisting of Sukshma Sarira etc, which is bound by Prakriti or Maya.

Visishtadvaitins accept three sources for knowledge (Pramanas): Pratyaksha, Anumana, Sabda. There are three Tatvas (Tatva-traya) Isvara, Jiva and Prakriti. Isvara or Brahman is the only independent reality. Jiva and Prakriti are realities dependent on Brahman.

\section{Brahman:}

Generally, Brahman can be defined as the Supreme Self that is beyond time, space and causation. He is limitless. He is tranquil. He shines with equal effulgence in all bodies. He cannot be any particular thing. He is Chaitanya or pure consciousness.

According to Ramanuja, whatever is, is Brahman; but, Brahman is not of a homogeneous nature. He contains within Himself elements 
of plurality on account of which He truly manifests Himself in a diversified world. Ramanuja's Brahman is essentially a Personal God, the all-powerful and all-wise Ruler of a real world, permeated and animated by His spirit. There is thus, no room for the distinction between Param Nirguna and an Aparam Saguna Brahman, between Brahman and Isvara. Ramanuja's Brahman is Savisesha Brahman, i.e., Brahman with attributes. ${ }^{4}$

Ramanuja's Brahman is not the Impersonal Absolute, but He is a Personal God, with the qualities of omnipotence, omniscience and infinite love. God is Saguna. When the Vedic texts declare that He is Nirguna, it means that there are no bases or lower qualities such as sorrow, pain, mortality, change and old age in Him.

The Lord is interpenetrating everything. He is the essence of the soul. He is the Antaryamin or the Inner Ruler. He is one with the soul. He is all-pervading (Vibhu). He is the Supreme Being. He is full of auspicious attributes. He is of the nature of Satya (Truth), Jnana (Intelligence) and Ananda (Bliss). Matter and soul depend on Him. He is the Adhara or support for this world and all souls. God is the Governor or Controller (Niyanta or Seshin) of the world. Jiva or soul is Niyama or Sesha (one who is being controlled).

The Lord is immanent. He is also transcendent. He is unchanging. The entire universe is latent in Him during Pralaya. The world is projected during creation, but this does not touch His essence. Ramanuja's Brahman has internal difference (Svagata Bheda). It is a synthetic whole, with souls and matter as its modes (Chit-AchitVisishta). Para, Vyuha, Vibhava, Archa and Antaryamin, i.e., the transcendent, the group, the incarnation, the image and the immanent are the five forms of the Lord.

The eternal is said to be five-fold, and worshipped in these five forms:

1. Para - The eternal being. This is Sri Maha Vishnu in times of non-creation in Vaikuntha, sleeping in the coils of infinity. 
2. Vyuha - The one with four aspects, Sankarshana, Vasudeva, Pradyumna and Aniruddha. Vishnu Sahasranama praises Him as Caturoyuha, or having four Vyuhas.

3. Antaryamin - The One (as soul) that pervades all creation.

4. Vibhava - The glorious incarnations of God, such as Sri Rama and Sri Krishna.

5. Arca - The forms of worship, such as incarnations and idols.

Ramanuja used the concept of co-ordinate predication to show how two aspects of Brahman can be distinct from each other yet inseparable. For example, the phrase "green tree" is an example of co-ordinate predication. The latter is a substance while the former is an attribute. In the same way, the universe, while distinct from Brahman, is still a part of Brahman -it is an attribute and not an independent principle capable of functioning on its own. In other words, the universe is dependent on and inseparable from God.

Ramanuja thought that souls and matter are utterly dependent on Brahman for their existence. Brahman is the Supreme Soul who is present in all finite souls and matter. Brahman dwells in the souls unrecognized and unknown until liberation (Moksha) is reached. During liberation, the finite souls realize their divine nature but do not become identical with God - Brahman and souls remain distinct yet inseparable.

\section{The World:}

The world, with its variety of material forms of existence and individual souls, is not an unreal Maya, but a real part of Brahman's nature. It is the body of the Lord. Matter is real. It is Achit or nonconscious substance. It undergoes a real Parinama or evolution. Matter exists in a subtle state as the Prakara of God during Pralaya. Hence it is eternal, but ever dependent. It is controlled by the will of God. It is neither good nor bad. It becomes a source of pleasure or of pain according to the nature of the Karma of souls. It forms the object of experience for the souls.

Prakriti has three Gunas: Sattva, Rajas and Tamas; but, Suddha-Tattoa has only Sattva. It is pure matter. Suddha-Tattva is the substance 
which constitutes the body of God and is called His Nitya-Vibhuti. The manifested world is His Lila-Vibhuti.

\section{The Soul:}

The soul is a higher Prakara of God than matter, because it is a conscious entity. It is of the essence of God. According to Ramanuja, God, soul and Nature are three eternal entities. The soul is self-conscious, unchanging, partless and atomic $(A n u)$. The souls are infinite in number. The individual soul of Ramanuja is a real individual. It is absolutely real and eternally distinct from God. It has indeed, sprung from Brahman, and is never outside Brahman; nevertheless, it enjoys a separate personal existence and will remain a personality forever.

\section{Three Classes of Souls:}

According to Ramanuja, there are three classes of souls, viz., Nitya (eternal), Mukta (free) and Baddha (bound). The eternal souls have never been in bondage. They are eternally free. They live with God in Vaikuntha. The freed souls were once subject to Samsara, but have attained salvation now and live with God. The bound souls are caught up in the meshes of Samsara and are striving to be released. They wander from life to life till they are redeemed.

Man or the individual soul is a particle of which God is the whole. The individual soul is like a spark of that mass of fire. The whole pomegranate fruit could be cited as an example of the concept of Brahman of Ramanuja, each seed corresponding to the individual soul.

\section{Moksha:}

When the individual soul is immersed in worldliness or Samsara, its knowledge is contracted. It gets its body according to its past Karma and goes from birth to death and from death to birth, till it attains Moksha or the final emancipation. When it attains Moksha, its knowledge expands. It knows everything. "Every action that contracts the heart of the soul is bad, and every action that expands the heart of the soul is good" - this is the statement of Ramanuja. 
The soul is marching on in this Samsara, expanding or contracting through its good and evil actions, till it attains the final emancipation through the grace of Lord Narayana. The grace descends on those souls who are pure and struggling for the divine grace.

According to Ramanuja, Moksha means the soul's passing from the troubles of mundane life into a kind of heaven or paradise (Vaikuntha) where it will remain forever in undisturbed personal bliss in the presence of God. The liberated soul attains to the nature of God. It never becomes identical with Him. It lives in fellowship with the Lord, either serving Him or meditating on Him. It never loses its individuality. There is no such thing as Jivanmukti (which is there in Advaita), according to Ramanuja. Salvation comes when the soul leaves the body.

\section{Bhakti:}

The final emancipation can be obtained only through Bhakti and the grace of the Lord. The grace of the Lord comes through devotion and Prapatti or absolute self-surrender. Karma and Jnana are only means to attain Bhakti.

\section{Wahdatul-Wujūd:}

Central to Islamic belief is the oneness or unity (in Arabic: Tawhid) of Allah or God. Not only is Allah separate from the material universe which He created and not only is there one and only one God, but Allah also is perfect and without parts; that is, Allah or God is a unity or singularity and it is this unity that makes up the perfection of Allah.

Being an Abrahamic religion, Islam has discussed the ontological concepts in the way of creationism and the Quran and the Haditht* have only touched upon the subject but have not discussed it in a detailed manner. Unlike discussing in a chronological way, creation has been outlined in different places in the Quran according to the contextual necessity.

\footnotetext{
$t^{*}$ A collection of traditions containing sayings of the prophet Muhammad which, with accounts of his daily practice, constitute the major source of guidance for Muslims apart from the Quran. 
But only after two centuries from the completion of the Quranic revelation, there were some Sufis who started a discussion about these philosophical and ontological concepts in Islam in a mystical way. The core discussion of their mystical interpretations was the existential reality of God, World/Universe, Soul, Man, the relationship among them, and so forth. Among those mystical and philosophical perspectives, Wahdatul-Wujūd (Unity of Existence) has played a dominant role in Islamic Thought. It had been introduced by Muhammad b. 'Ali Ibn Arabi (also known by the name - Muhiuddin Ibn Arabi) in Spain. In the beginning, it was just a philosophical thought discussed among only a few Sufi circles. But as it spread across the Muslim world, it had created many misunderstandings within Islam and the outside. So, it had been straightforwardly condemned by mainstream Islamic scholars. Similarly in Indian philosophy, schools of Vedānta played a very influential role. After Advaita Vedānta, Visistādvaita played a great role in interpreting core philosophical concepts of Upanishads, Bhagavad Gita and BrahmaSutras.

Wahdatul-Wujūd as explained by Muhammad b. 'Ali Ibn Arabi (d. 1240) recognizes the existence of only One Being, negating the existence of all other Beings. As the term is self-explanatory, Wahdutul Wujüd means there is only One Being and the physical world is a manifestation of the One Being. Nothing exists besides the One Being. The essential components of the philosophy of Wahdatul-Wujüd could be explained in three points - there is in reality only One Being, the One Being has no parts, and the One Being is neither more here, nor less there. According to the followers of Ibn Arabi as well as the Muslim scholastic theologians, God is the only being whose existence depends on his own existence. In this sense, existence belongs only to God, who cannot not exist ${ }^{5}$. Furthermore, this existence accepts neither multiplicity nor division, nor transformation. Having no form or limit, the Existence, at this stage, is so pure and absolute that it is not delimited even by the concept of non-delimitation. One cannot understand through reason the Existence through reason at this stage. 
The Sufis of Wahdatul-Wujūd very often explain the relationship between God and the cosmos using analogies such as the following; in respect to the existence of the cosmos, the existence of Reality is like a mirror wherein all intelligible and sensible things appeared. In other words, Reality manifests Himself in respect of His attributes or names, not in respect of His Essence, in every form and individual, without losing His absoluteness and undergoing neither transformation nor transmutation. In the latter respect, all creatures become like a mirror wherein God discloses Himself 6 .

The question that must be answered is how the One Being manifests itself or through what process does it become a physical form? According to Ibn Arabi, the One Being knows how to create plurality from its unity and such a form of creation is known as "Ta'ayyun" (determination). The physical forms and manifestations begin to occur through this recess of Ta'ayyun. This does not mean that the Being is divisible. The manifestations of the One Being in whichever form they appear are the representation of the One Being in its entirety.

Ibn al-'Arabī and his followers held an absolute monism by saying that the real existence belongs merely to God and the other beings have no existence in an actual sense. They attempted to overcome this problem by a scheme of seven-stage hierarchy known as $\mathrm{Al}$ marātib al-Sab'a. These stages can be outlined as follows?:

1. The Absolute Existence or the Stage of NonDetermination - Ahadiyah: In this stage, the Existence is in the mode of Pure Essence and far away from any name, attribute, quality, and action. He is so unconditioned that He is far away even from the restriction of non-delimitation. In one respect, determination or individualization involves the sense of being restricted and distinguished. This stage is also called Martabah-e-LäTa'ayyun or Ghaibul Ghaib.

2. First Determination or the Stage of Unity - Wahdah: This stage is called thus because the Essence self-manifests in Himself by Himself and for Himself. This self-manifestation is caused by the necessity of the Essence. In this stage, the Essence knows His names and attributes in a universal way. The Essence is called by the name Allāh, which brings 
together all the names in Himself. In this stage, neither God nor His attributes are differentiated from the creatures nor are the creatures differentiated from one another. One cannot imagine an existence for the creatures in the Essence and His attributes nor can one imagine that the Essence and His attributes have existence in the creatures. This stage is also known as the Stage of Outline - Martabah-e-Ijmali or Reality of Muhammad - Haqiqat-e-Muhammadiyah.

3. Second Determination - Wahidiyah: In this stage, the Real knows his Essence, names and attributes as well as all the creatures in differentiation. The Sufis explain the second and third stage by the seed analogy. A seed is the origin of a tree. If we take this seed as something "knowing itself," so it's thinking of itself without the distinction of its features and details - like its root, stem, bud, shoots, leaves, flowers, and fruits - its knowledge can be compared to the first determination or individualization. And the seed's thinking of these details and features, in general, can be likened to the second determination. This stage is called Martabah-eTafseel and also called Haqiqat-e-Insan.

4. The Domain of Spirits - Alam-e-Arwah: In this stage, the archetypes of the divine knowledge appear as simple substances, which have neither shape nor color, nor are limited by time or space as the qualities of temporality and spatiality are features of corporeal things. In this stage, each spirit knows itself, its similarity to its God on the stage of Lordship. That is the first stage where the concept of Otherness appears. This stage is about reality of all souls.

5. The Domain of Imagination or Similarity - Alam-eMitsal: This stage is situated between the stage of spirits and corporeal bodies. In this stage, the Absolute Being selfmanifests in the forms which accept no division, separation, or union. This stage is referred to as the domain of similarity, as in this domain there emerges a form resembling the form of each which appears in the domain of 
the corporeal. The Sufis term this stage as the domain of imagination because man can perceive this domain through his faculty of imagination. This stage is about reality of all spheres and also called state of composition.

6. The World of the Visible or The Domain of the Corporeal - Alam-e-Ajsam: This domain is composed of dense, cosmic, and compound bodies which accept particularization and division. In this stage, the Absolute Being self-manifests outwardly in the forms of matter and corporeal things. In this stage, the forms can be broken apart, dissolved, and re-united. This stage is called the domain of the visible and sensible, for man can perceive this domain through his senses. This stage is about the reality of all bodies.

7. The Stage of the Perfect Man - Al-Insan-al-Kamil: This is the last stage of the existential, the ophany. We can summarize the views of Sufis about the doctrine of the Perfect Man. The human being is the reason for the creation of the cosmos and the most perfect being among all other creatures. In respect of his physical constitution, involving a sample of every cosmic element, man is the last created being; but in respect of his spiritual aspect, he is the first created being. His spirit was temporally originated by the divine breath. Thus, he became unique in being able to perceive the realities of things and the divine mysteries and was able to bring together all the divine names and attributes in himself. Since the origin of the human being is the Divine Essence, he also possesses the names of Majesty and Beauty. If man traverses through all the spiritual stages and achieves spiritual perfection under the supervision of a perfect spiritual guide, he becomes like a mirror wherein all the divine names and attributes which are latent in him manifest themselves. However, man has a double nature; corporeal and spiritual. Thus, whereas his corporeal aspect, which is referred to as Al-nafs Al-ammāra or the lower soul, tends towards the worldly pleasures and vile things and finally falls into the most base of base degrees, his soul of 
divine origin aspires to re-unite with God. Thus, the human being is like a battleground where two opposite forces fight. The task of man is to purify the soul which was veiled by seven veils during its descent to the physical world by traversing back through the spiritual stages. Whoever realizes this journey, he/she attains to the station of the perfect man and the vicegerent of God on earth.

According to the concept of Wahdatul-Wujūd, there are three types of manifestations, i.e., spiritual, symbolic, or physical of the One Being. Thus the unity and the plurality are the same Being in various forms manifesting as spiritual, symbolic or physical. According to this, there would be no essential difference between the plurality that we see and the transcendental unity from which it emerged. According to this, essence of God in the physical form suffers, wills and takes pleasure in the enjoyment of the physical world as a part of it. His transcendence is still maintained in so far as he is infinite and eternal in the Ahadiyah stage. These attributes are not expressed as corporeal determinations and would not be demonstrated in any physical forms that the Being may assume. This plurality of physical forms, based on the realization that it is truly one with the Divine, also strives to achieve union with the Being again, and this begs the question: what is the driving force behind this movement towards unity?

Upon examination of the Sufi philosophy, one learns that what propels this movement towards union is the force of Love, God intoxication or Ishq. It is this force that motivates union with the Divine as an intensely powerful feeling compelling the Sufi to acknowledge that his soul is Divine, but that it is trapped in a physical body. The Sufi, therefore, attempts to seek the Divine by denying the body the physical or worldly pleasures. He hopes that by denying himself the worldly pleasures, the love of the Divine will increase.

The Sufi observes Zikr or the remembrance of Allāh, which will bring about the unitive experience. When the unitive experience is realized, the Sufi may declare himself or herself God because he 
begins to see that there is in reality only One Being and also begins to believe in the unity of existence or the concept of WahdatulWujūd.

\section{Points to compare:}

First of all, it is to be remembered that both the philosophies are interpretations based on the respective religious scriptures. In other words, they are not direct religious or primary scriptures. Visishtädvaita is an interpretation based on Upanișads and consolidated in the Brahma Sütra, and Wahdatul-Wujüdis is based on a selected ontological perspectives and concepts from Sufism. Both philosophies are just one of the interpretations but not the only authentic interpretation in the respective religions under which they are classified. Both the philosophies faced several criticisms from other schools within the same religions. Moreover, WahdatulWujüd is not completely backed by the authentic sources of Islam, i.e. the Quran and the Hadith.

Related to the naming of both the concepts, Visishtädvaita is a combination of two words - Visishta and Advaita. Advaita means "no-two" or "not-two" in Sanskrit which denotes that only One Existence is there and nothing else exists, and Visishta means "qualified" in Sanskrit. Wahdatul-Wujūd means "Unity of Existence" in Arabic denotes that only One Essence behind every existence.

In both Visishtādvaita and Wahdatul-Wujūd, the discussion is based on the existence and the creation. This ontological discussion introduces many concepts like Brahman, Jiva, Ahadiyah, Wahdah, Wahidiyah, World, Bhakti, Prakriti/Maya, Karma, Moksha and different Alams or domains like Alam-e-Arwah, Alam-e-Mitsal, Alam$e$-Ajsam, etc. Both philosophies agree that the only Existence there is, is that of the Supreme Reality along with some dependent entities. The attribute-less reality cannot be perceived nor could it be described by words. It is beyond senses and intellect. It is indefinable, eternal, immutable, inexpressible and unthinkable pure-existence.

Nirguna Brahman which is explained by Visishtädvaita is similar to the stage of Ahadiyah of Wahdatul-Wujūd. Similarly, Saguna Brahman of Visishtädvaita is similar to the stage of Wahdah. 
Both Visishtādvaita and Wahdatul-Wujūd agree on the concept of Jiva or Spirit in one way or the other. Both philosophies say that Spirit depends on the Being. In other words, Visishtädvaita says Brahman and Jiva are not one and same; Wahdatul-Wujūd says they are different regarding delimited existence, but they are same in terms of the essence.

\section{Points of departure:}

Even though, some similarities are there between Nirguna Bramhan and Ahadiyah, and Saguna Brahman and Wahdah, there are few differences. In Visishtādvaita, Nirguna/Para Bramhan and Saguna Bramhan are not stages but in Wahdatul-Wujūd they are.

According to Visishtādvaita, Bramhan is Chit-Achit-Visishta and SvagataBheda. These same attributes in combination are not available in Wahdatul-Wujūd.

Visishtädvaita and Wahdatul-Wujūd accept the concept Jiva or spirit but with different interpretations. In Visishtädvaita, Jiva depends on Bramhan. In Wahdatul-Wujūd, the Being manifests (Ta'ayun) Himself and reaches the stage of the domain of Spirits (Alam-e-Arwah); that means the Being and the spirit are not same.

There is a five-fold theory of the eternal Being to worship in Visishtādvaita, but it is not available in Wahdatul-Wujūd.

The concepts of Maya cannot be identified in Wahdatul-Wujūd. In the same way, the concept of Haqiqat-e-Muhammadiyah (the reality of Muhammad) is not visible in Visishtädvaita.

In Visishtādvaita, a manifestation of Brahman in different stages is not described. But in Wahdatul-Wujūd, it has been described in seven stages.

The Sufis observe Zikr and prefer the reunification called "FanaFillah" with the force of Love, God, intoxication or Ishq. According to Sufis, it is the force that motivates union with the Divine as an intensely powerful feeling compelling the Sufi to acknowledge that his soul is Divine, but that it is trapped in a physical body. Even though this objective is not cited anywhere in the Quran, and the 
Hadith but Sufis rationalize this with their mystical interpretations. This resembles Moksha. According to the Quran and the Hadith, Moksha is liberation from this world and attaining paradise hereafter.

Visishtädvaita believes in birth and rebirth in this world for many times, also called reincarnation but Wahdatul-Wujüd does not.

\section{Conclusion:}

This paper has tried to describe and explain Visishtädvaita and Wahdatul-Wujūd in a systematic manner and has tried to analyze, compare and contrast a few key concepts integral to these philosophical approaches. In conclusion, there are many similarities. However, they also have a few significant differences. The tables (Table 1.1 and Table 1.2) below summarize the insights presented in the paper.

Table 1.1 Similarities between Visishtādvaita and Wahdatul-Wujūd

\begin{tabular}{|c|c|c|c|}
\hline SN & Key Point & Visishtādvaita & Wahdatul-Wujūd \\
\hline 1 & Type & $\begin{array}{l}\text { Philosophical } \\
\text { interpretation; } \\
\text { not an original source }\end{array}$ & $\begin{array}{l}\text { Philosophical } \\
\text { interpretation; } \\
\text { not an original source }\end{array}$ \\
\hline 2 & Sources & $\begin{array}{l}\text { Upanișads, Bhagavad Gita } \\
\text { and Brahma Sütra }\end{array}$ & $\begin{array}{l}\text { Some (not all) Quranic } \\
\text { verses and few Hadiths }\end{array}$ \\
\hline 3 & $\begin{array}{l}\text { Authenticity } \\
\text { and } \\
\text { Acceptance }\end{array}$ & $\begin{array}{l}\text { Not accepted by all; } \\
\text { contradicted by Advaita, } \\
\text { Dvaita, etc. }\end{array}$ & $\begin{array}{l}\text { Not accepted by all; } \\
\text { contradicted and } \\
\text { rejected by mainstream } \\
\text { Islamic Scholars due to } \\
\text { involvement/resembla } \\
\text { nce of Shirk. }\end{array}$ \\
\hline 4 & Meaning & $\begin{array}{l}\text { 'no-two with } \\
\text { qualifications' or 'not-two } \\
\text { with qualifications.' }\end{array}$ & $\begin{array}{l}\text { 'Unity of Existence' or } \\
\text { 'Unity of Being.' }\end{array}$ \\
\hline 5 & $\begin{array}{l}\text { Bottom-line } \\
\text { philosophy }\end{array}$ & $\begin{array}{l}\text { Only one Existence } \\
\text { (Vishnu) behind every } \\
\text { existence. }\end{array}$ & $\begin{array}{l}\text { Only one Essence } \\
\text { behind every existence. }\end{array}$ \\
\hline 6 & $\begin{array}{l}\text { Main } \\
\text { commonality }\end{array}$ & \multicolumn{2}{|l|}{ Discussion on the Existence } \\
\hline 7 & Key concepts & $\begin{array}{l}\text { Brahman, Jiva, Prakriti, } \\
\text { Moksha, etc. }\end{array}$ & $\begin{array}{l}\text { Ahadiyah, Wahdah, } \\
\text { Wahidiyah, Jahalah, etc. }\end{array}$ \\
\hline 8 & Reality & Only one & Only one \\
\hline
\end{tabular}




\begin{tabular}{|c|c|c|c|}
\hline & & $\begin{array}{l}\text { Existence/Supreme } \\
\text { Reality }\end{array}$ & $\begin{array}{l}\text { Existence/Supreme } \\
\text { Reality }\end{array}$ \\
\hline \multirow[t]{2}{*}{9} & $\begin{array}{l}\text { Common } \\
\text { interpretation } \\
\text { of the Reality }\end{array}$ & Nirguna Brahman & Ahadiyah \\
\hline & & Saguna Brahman & Wahdah \\
\hline 10 & God & $\begin{array}{l}\text { Saguna Brahman is } \\
\text { Ishwara. } \\
\text { He is the Creator, the } \\
\text { Sustainer, and the } \\
\text { Destroyer. }\end{array}$ & $\begin{array}{l}\text { The stage of Wahdah is } \\
\text { Allāh. } \\
\text { He is the Creator, the } \\
\text { Sustainer and the } \\
\text { Destroyer with all other } \\
\text { attributes. }\end{array}$ \\
\hline 11 & $\begin{array}{l}\text { Concept of } \\
\text { God }\end{array}$ & Panentheism & Panentheism \\
\hline 12 & Jiva/Arwah & Jiva is not Brahman. & $\begin{array}{l}\text { The Being manifests } \\
\text { (Ta'ayun) Himself and } \\
\text { reaches the stage of } \\
\text { Alam-e-Arwah. }\end{array}$ \\
\hline 13 & $\begin{array}{l}\text { Reason of } \\
\text { Bondage }\end{array}$ & Avidya & Jahalah \\
\hline
\end{tabular}

Table 1.2 Differences between Visishtādvaita and Wahdatul-Wujūd

\begin{tabular}{|c|c|c|c|}
\hline $\begin{array}{l}\mathrm{S} \\
\mathbf{N}\end{array}$ & Key Point & Visishtādvaita & Wahdatul-Wujūd \\
\hline 1 & $\begin{array}{l}\text { The stages of } \\
\text { the Existence }\end{array}$ & $\begin{array}{l}\text { Nirguna Bramhan and } \\
\text { SagunaBrahman are not } \\
\text { stages. }\end{array}$ & $\begin{array}{l}\text { Ahadiyah and Wahdahare } \\
\text { stages. }\end{array}$ \\
\hline 2 & $\begin{array}{l}\text { Para, Vyuha, } \\
\text { Vibhava, Archa } \\
\text { and Antaryamin }\end{array}$ & $\begin{array}{l}\text { Bramhan is worshipped } \\
\text { in five-folds: Para, } \\
\text { Vyuha, Vibhava, Archa } \\
\text { and Antaryamin. }\end{array}$ & Not defined like this. \\
\hline 4 & $\begin{array}{l}\text { Concept of } \\
\text { Haqiqat-e- } \\
\text { Muhammadiyah }\end{array}$ & Not present. & $\begin{array}{l}\text { Wahdah is Haqiqat-e- } \\
\text { Muhammad-iyah }\end{array}$ \\
\hline 6 & $\begin{array}{l}\text { Stages of } \\
\text { manifestation }\end{array}$ & Not discussed in-detail & They are discussed \\
\hline 7 & $\begin{array}{l}\text { Means of } \\
\text { Moksha }\end{array}$ & $\begin{array}{l}\text { Karma and Jnana are } \\
\text { only means to Bhakti. }\end{array}$ & $\begin{array}{l}\text { Similar to Gnana and } \\
\text { Bhakti Yoga - Fana-Fillah }\end{array}$ \\
\hline
\end{tabular}




\begin{tabular}{|l|l|l|l|}
\hline 8 & $\begin{array}{l}\text { Concept of } \\
\text { reincarnation }\end{array}$ & $\begin{array}{l}\text { Justifies the concept of } \\
\text { rebirth. }\end{array}$ & No concept of rebirth. \\
\hline
\end{tabular}

\section{References:}

1. Wehr, H. (1976). A Dictionary of Modern Written Arabic. M. Cowan (ed.) (3 ${ }^{\text {rd }}$ ed.). New York: Spoken Language Services.

2. Kamoonpuri, S. (2001). Basic Beliefs of Islam. Tanzania: Tanzania Printers Limited.

3. The Quran. (n.d.). 4:48

4. Sri Sivananda, Swami. (1947). All about Hinduism, Shivanandanagar: The Divine Life Society.

5. Fenni Ertuğrul, İsmail. (1991). Vahdet-i Vücûd ve İbn Arabi M. Kara (Ed.).Istabul: İnsan Yayınları.

6. Affifi, A. E. (1938). The Mystical Philosophy of Ibnu'l-Arabi. Lahore:Ashraf Press.

7. Chittick, W. C. (1994). Imaginal worlds: Ibn al-'Arabi and the problem of religious diversity. SUNY Press.

8. Chittick, W. C. (2010). The Sufi path of knowledge: Ibn alArabi's metaphysics of imagination. Suny Press. 